\title{
'SETTING THE BOUNDARIES OF ACCEPTABLE BEHAVIOUR'? SOUTH AUSTRALIA'S LATEST LEGISLATIVE RESPONSE TO REVENGE PORNOGRAPHY
}

\author{
DAVID PLATER*
}

The complex contemporary issue of revenge pornography has attracted extensive media, law reform and academic commentary and concern, especially as to the perceived failures of both the civil and criminal law to keep up to date with social and technological changes and to adequately respond to this issue. This article considers the existing remedies under the criminal law to revenge pornography and examines the Summary Offences (Filming and Sexting Offences) Amendment Act 2016 (SA) that came into operation on 28 October 2016. The new Act updates and strengthens the criminal law in South Australia in this area. This article notes that the criminal law is not the exclusive means to address revenge pornography and that there is a need for a wider approach that includes effective civil legal remedies and education and cultural change. However, the criminal law still has a vital role to play in setting the boundaries of acceptable modern behaviour. In this light, it is argued that the new South Australian Act is a timely and welcome legislative addition in addressing revenge pornography.

\section{CONTENTS}

Introduction 78

II The Criminal Law and Revenge Pornography..... 82

III The Present South Australian Criminal Law 85

IV The Criminal Law Is Not Enough................................................ 89

V Conclusion: The Need for a Comprehensive Solution. 93

BA LLB (Monash University), LLM (Inns of Court Law School, London), PhD (University of Tasmania); Deputy Director, South Australian Law Reform Institute; Senior Lecturer, Adelaide Law School, University of Adelaide. Any views expressed in this article are those of the author alone and expressed in a personal capacity. The author is grateful for the comments of Jonathan Polnay of 5 Kings Bench Walk, London, Associate Professor Julia Davis and Rebekah Mudri. 


\section{INTRODUCTION:}

'Revenge Porn: ${ }^{1}$ The world is moving on while Australia stands still.' 2 This was the bleak headline of a recent article highlighting the limitations of the Australian legal response, especially in updating relevant laws, to address the complex contemporary problem of revenge pornography. ${ }^{3}$ The current law in Australia in relation to revenge pornography has been criticised as

1 It is accepted that the term 'revenge pornography' is less than ideal. The Senate Legal and Constitutional Affairs Reference Committee ('Senate Committee') during the course of its recent inquiry heard opposition to and concern about the use of the phrase 'revenge porn' and noted:

The Committee shares the concerns raised in relation to the connotations of 'revenge porn' and the Committee agrees that there are more appropriate terms — such as 'non-consensual sharing of intimate images' - that should be used instead; this terminology reflects that a variety of motives are relevant and that not all images are created or distributed for the purposes of pornography.

Senate Legal and Constitutional Affairs Reference Committee, Parliament of Australia, Phenomenon Colloquially Referred to as 'Revenge Porn', which Involves Sharing Private Sexual Images and Recordings of a Person without their Consent, with the Intention to Cause that Person Harm (2016) 1 [1.5], see also 15-6 [2.2]-[2.9], 49 [5.4]-[5.6]. Because the term 'revenge porn' is used so frequently as shorthand for all forms of nonconsensual pornography, this article uses 'revenge pornography' in preference to 'nonconsensual pornography'; see Danielle Citron and Mary Franks, 'Criminalising Revenge Porn' (2014) 49 Wake Forest Law Review 345, 346.

2 Rohan Smith, 'Revenge Porn: The World is Moving on while Australia Stands Still', news.com.au (online), 20 March 2015,

<http://www.news.com.au/technology/online/security/revenge-porn-the-world-is-movingon-while-australia-stands-still/news-story/7fbf6c057bba5d54dca344a26073126e>.

3 Revenge pornography:

involves the distribution of sexually graphic images of individuals without their consent. This includes images originally obtained without consent (eg, hidden recordings or recordings of sexual assaults) as well as images originally obtained with consent, usually within the context of a private or confidential relationship (eg, images consensually given to an intimate partner who later distributes them without consent, popularly referred to as 'revenge porn'):

Citron and Franks, above n 1, 345, 346. See also Senate Committee, above n 1, 2-3 [1.12][1.15]. Although revenge pornography is often perpetrated by former romantic partners who distribute intimate images seeking revenge, it "can also involve acquaintances or strangers who distribute images in order to coerce, blackmail, humiliate or embarrass another person, or those who distribute images for sexual gratification, fun, social notoriety or financial gain': Drs Nicola Henry, Asher Flynn and Anastasia Powell, Submission 9, 3, quoted by Senate Committee, above n 1, 2 [1.14]. 
'unacceptable', 4 'piecemeal', 5 'inadequate' ${ }^{6}$ and containing 'glaring gaps and inconsistencies'. ${ }^{7}$ There are particular problems in ensuring that the law remains effective in keeping up with technological advances. ${ }^{8}$ 'There is a disconnect, rapidly widening, between the speed of technological innovation and the laws set up to govern what goes on in cyberspace.' 9

Despite such gloomy predictions, Australian law reform bodies and legislators have not been idle. There has been a plethora of recent calls from various reviews for new civil and/or criminal laws to counter serious invasions of privacy in general or revenge pornography in particular. ${ }^{10}$ Victoria already has relatively recent specific laws in place ${ }^{11}$ and both New South Wales ${ }^{12}$ and

4 Senate Committee, above n 1, 50 [5.9].

5 Elle Hunt, 'Victoria Leads Way in Piecemeal Approach to Outlawing Revenge Porn', The Guardian (online), 5 September 2016, <https://www.theguardian.com/australianews/2016/sep/05/victoria-leads-way-in-piecemeal-approach-to-outlawing-revenge-porn>.

6 Miles Godfrey, 'Revenge Porn Spreading like Wildfire', The Australian (online), 22 November 2013, <http://www.theaustralian.com.au/news/latest-news/revenge-pornspreading-like-wildfire/story-fn3dxiwe-1226766034486>.

7 AAP, 'NSW Govt to Consider “Revenge Porn” Laws', The Australian (online), 3 March 2016, <http://www.theaustralian.com.au/news/latest-news/let-revenge-porn-victims-sue-nswreport/news-story/e620808a31d2578c773627c9c3451257>.

8 See, eg, Godfrey, above n 6; Wilson v Ferguson [2015] WASC15 [79]-[81]; Cosima Marriner, 'Revenge Porn: Government Urged to Make it Illegal', Sydney Morning Herald (online), 4 October 2015, <http://www.smh.com.au/national/government-urged-to-outlaw-revengeporn-20150926-gjvod5.html>.

9 Milo Yiannopoulos, 'The Law Must Learn to Keep up with Technology', The Telegraph (online), 12 November 2010, <http://www.telegraph.co.uk/technology/twitter/8128252/Thelaw-must-learn-to-keep-up-with-technology.html>.

10 See, eg, Australian Law Reform Commission, For Your Information: Privacy Law and Practice (Report 108) (2008); New South Wales Law Reform Commission, Invasion of Privacy (Report 120) (2009); Victorian Law Reform Commission, Surveillance in Public Places (Report 18) (2010); Australian Law Reform Commission, Serious Invasions of Privacy in the Digital Era (Report 123) (2014); South Australian Law Reform Institute, A Statutory Tort for Invasion of Privacy (2016); Senate Committee, above n 1; Standing Committee on Law and Justice ('NSW Standing Committee'), Parliament of New South Wales, Remedies for the Serious Invasion of Privacy in New South Wales (2016).

11 Summary Offences Act 1966 (Vic) ss 41DA-41DB.

12 See Lucy McNally, "Revenge Porn" to be Criminalised in Response to NSW Privacy Inquiry', ABC News (online), 5 September 2016, http://www.abc.net.au/news/2016-0905/criminalising-'revenge-porn'-in-nsw-a-step-closer/7813446; AAP, 'New South Wales Plans Laws to Outlaw Revenge Porn after Privacy Inquiry', The Guardian (online), 5 September 2016, <https://www.theguardian.com/australia-news/2016/sep/05/new-southwales-plans-laws-to-outlaw-revenge-porn-after-privacy-inquiry>. 
Western Australia ${ }^{13}$ have announced their intention to legislate in this area in the near future. However, it is South Australia that appears to be the leading Australia jurisdiction in this area (at least legislatively). The Summary Offences (Filming and Sexting Offences) Amendment Act 2016 passed the South Australian Parliament with all party support ${ }^{14}$ and came into operation on 28 October 2016.

The new Act clarifies and strengthens the criminal law in South Australia regarding revenge pornography. As the South Australian Attorney-General, the Hon John Rau, explained, the new Act 'reflects changing social and technological trends and reaffirms standards of appropriate conduct, especially involving the use of invasive images depicting minors.' ${ }^{15}$

The nature and extent of the problem of revenge pornography is now well established. ${ }^{16}$ The Attorney-General, in introducing the new South Australian Act, noted the 'distasteful' phenomenon of revenge pornography which involves 'the publication of explicit material portraying somebody who has not consented for the material to be shared, often with the purpose of causing humiliation, embarrassment or distress' and noted that 'sexing-type images of adults and minors are commonly being used, whether by adults or minors, ${ }^{17}$ as

13 AAP, 'Revenge Porn to be Criminalised in Western Australia Domestic Violence Law', The Guardian (online), 11 September 2016,

<https://www.theguardian.com/society/2016/sep/11/revenge-porn-to-be-criminalised-inwestern-australia-domestic-violence-law>.

14 South Australia, Parliamentary Debates, House of Assembly, 17 May 2016, 5314-21; South Australia, Parliamentary Debates, Legislative Council, 9 June 2016, 4248-52.

15 South Australia, Parliamentary Debates, House of Assembly, 9 March 2016, 4602.

16 See, eg, Senate Committee, above n 1, 20-1 [2.23]-[2.28]; Samantha Bates, 'Revenge Porn and Mental Health: A Qualitative Analysis of the Mental Health Effects of Revenge Porn on Female Survivors' (2017) 12 Feminist Criminology 22; Citron and Franks, above n 1, 350-4; Zak Franklin, 'Justice for Revenge Porn Victims: Legal Theories to Overcome Claims of Civil Immunity by Operators of Revenge Porn Websites' (2014) 102 California Law Review 1303, 1304-5, 1309-11; Adrienne Kitchen, 'The Need to Criminalize Revenge Porn: How a Law Protecting Victims Can Avoid Running Afoul of the First Amendment' (2015) 90 ChicagoKent Law Review 246, 246-50, 263-6. It has been reported that at least 3000 websites 'feature the revenge genre': NSW Standing Committee, above n 10, 19 [2.11].

17 There is a view that the current legal frameworks in Australia may apply unfairly to children engaging in 'sexting' who may fall foul of child pornography laws that are said to be ill designed to deal with such practices and from which age provides little protection. It is argued that the existing laws lack the capacity to discriminate between a broad range of activities with different motivations, the presence or absence of consent, and differing levels of potential harm and that the current legislative frameworks have the potential to produce more harms than many of the practices they seek to regulate. Indeed, it is argued that young people face prosecution for child pornography offences and 'being placed on sex offender registers for 
a tool of revenge, bullying, vilification or harassment or even as a form of domestic violence ${ }^{18} \ldots$ This is a major source of current concern. ${ }^{19}$

The recent Report of the Senate Committee into the Phenomenon Colloquially Referred to as Revenge Porn elaborated on some of the concerns raised by revenge pornography:

Non-consensual sharing of intimate images is a serious and growing problem in Australia, facilitated in part by technological advances and increasing use of social media. Non-consensual sharing of intimate images can have a significant impact on victim, psychologically and physically, as well as being damaging to the victim's reputation and standing. ${ }^{20}$

The likely lasting nature of the image and the potential for revictimisation and distress is significant. ${ }^{21}$ 'We all know that once an image hits cyberspace and

behaviour they may think of as simply having some fun among friends'; Thomas Crofts and Murray Lee, “'Sexting”, Children and Child Pornography' (2013) 35(1) Sydney Law Review 85. See also Michael Salter, Thomas Croft and Murray Lee, 'Beyond Criminalisation and Responsibilisation: Sexting, Gender and Young People' (2013) 24(3) Current Issues in Criminal Justice 301. This view, however, arguably overlooks the fact that some persons under 18 who engage in such conduct are not merely 'sexting'. As the South Australian Attorney-General noted in debate, it is important to avoid any assumption that young offenders who deal with sexually explicit material depicting a child aged under 17 'are simply naïve or misguided individuals ... there are some young South Australia offenders who use such images as a form of unacceptable bullying (including, as revenge pornography)': Parliamentary Debates, House of Assembly, 9 March 2016, 4602 (John Rau, AttorneyGeneral). See also: South Australia, Parliamentary Debates, House of Assembly, 17 May 2016, 5308 (John Rau, Attorney-General); South Australia, Parliamentary Debates, House of Assembly, 17 May 2016, 5318 (Mr Tarzia); South Australia, Parliamentary Debates, Legislative Council, 9 June 2016, 4251 (Hon T Franks).

18 The nexus between revenge pornography and domestic violence is significant. See, eg, NSW Standing Committee, above n 10, 20 [2.16]; 21-2 [2.19]-[2.21]; Senate Committee, above n 1, 17 [2.10]-[2.12], 19 [2.19]-[2.20], 35 [3.39]; Citron and Franks, above n 1, 351.

19 South Australia, Parliamentary Debates, House of Assembly, 9 March 2016, 4602 (John Rau, Attorney-General).

20 Senate Committee, above n 1, 49 [5.1]. Gabrielle Upton, the NSW Attorney-General, has said that 'No one has the right to share explicit photos without consent ... this kind of behaviour is totally unacceptable ... These images can have a devastating emotional and social effect on the person pictured and can be used as a way to deliberately humiliate, control or harass the intended victim': AAP, 'New South Wales Plans Laws to Outlaw Revenge Porn after Privacy Inquiry' The Guardian (online), 5 September 2016, <https://www.theguardian.com/australianews/2016/sep/05/new-south-wales-plans-laws-to-outlaw-revenge-porn-after-privacyinquiry>.

21 Kitchen, above n 16, 249-50. 
is in the internet history it is there forever. ${ }^{22}$ It is difficult, if not virtually impossible, to remove the results of revenge pornography once it has reached the internet. ${ }^{23}$

\section{THE CRIMINAL LAW AND REVENGE PORNOGRAPHY}

The criminal law plays a vital, though, not exclusive, role in addressing revenge pornography. It is an area within the concurrent criminal jurisdiction of both the Commonwealth and the states and territories. There are various offences that exist under both Commonwealth and South Australian law that could apply to revenge pornography.

There are various potential offences in the Commonwealth Criminal Code. Part 10.6 of the Criminal Code Act 1995 (Cth) provides for offences relating to the misuse of a telecommunications service with a maximum penalty of three years imprisonment. Under s 474.17 of the Code, a person is guilty of an offence if the person uses a carriage service and the person does so in a way (whether by the method of use or the content of a communication, or both) that reasonable persons would regard as being, in all the circumstances, menacing, harassing or offensive. The individual must have intended to use the carriage service and have been reckless as to whether they were using a carriage service in a way that the reasonable person would regard in all the circumstances as menacing, harassing or offensive. The reasonable person test allows for community standards and common sense to be taken into account when determining whether certain conduct or the content of a communication is in fact menacing, harassing or offensive. ${ }^{24}$

Other provisions of the Criminal Code (Cth) that are potentially applicable include s 471.12 (criminalising the use of a postal or similar service to menace, harass or cause offence) and s 474.19 and s 474.20 (criminalising the use of a carriage service for child pornography). Section 474.25 establishes offences related to the obligations of internet service providers and internet content hosts with regard to child pornography and child abuse material.

There are no Commonwealth offences that specifically address revenge pornography. The current Commonwealth criminal laws are widely considered

22 South Australia, Parliamentary Debates, House of Assembly, 17 May 2016, 5319 (Mr Tarzia).

23 Kitchen, above n 16, 251.

24 Senate Committee, above n 1, 5 [1.25]. 
to be inadequate. ${ }^{25}$ The Commonwealth DPP has observed that 'there are limitations on existing Commonwealth laws to adequately deal with "revenge porn" conduct'. ${ }^{26}$ The Senate Committee was 'particularly concerned about the limited avenues at criminal law for victims of non-consensual sharing of intimate images to currently seek redress' ${ }^{27}$ and noted the 'overwhelming support ${ }^{28}$ it received in its consultation for legislative change, including at the Commonwealth level. The Senate Committee was 'left in no doubt about the need for legislation' and argued that the Commonwealth should 'demonstrate leadership in this regard' and legislate to the extent of its constitutional power to introduce new offences of knowingly or recklessly recording or sharing an intimate image without consent and threatening to take and/or share intimate images without consent, irrespective of whether or not those images exist. ${ }^{29}$

The Senate Committee also recommended that the states and territories enact their own legislation with offences the same or at least substantially similar to those recommended by the Committee, taking into account any relevant offences enacted by the Commonwealth. ${ }^{30}$ Only Victoria and South Australia currently have such specific laws.

There are various offences under South Australian law that may apply to revenge pornography situations. These include offences relating to the

25 See Senate Committee, above n 1, 27-31 [3.1]-[3.19], 51-2 [5.16]-[5.17]. The Criminal Code Amendment (Private Sexual Material) Bill 2016 (Cth) was introduced on 17 October 2016 to address this omission.

26 AAP, 'Top Prosecutor Warns Australia's Revenge Porn Laws are too Weak to Properly Protect Women', News.com.au (online) 10 January 2016,

<http://www.news.com.au/technology/online/security/top-prosecutor-warns-australiasrevenge-porn-laws-are-too-weak-to-properly-protect-women/newsstory/b597b7c0f1b0f76c7b7980ca545b512a>.

27 Senate Committee, above n 1, 50 [5.9].

28 Ibid 50 [5.8].

29 Ibid 51-2 [5.17]-[5.18]. The Criminal Code Amendment (Private Sexual Material) Bill 2015 (Cth) was introduced in 2015. The Bill lapsed with the 2016 federal election. The Commonwealth Minister for Women, Michaelia Cash MP, has previously reported that the issue of technology-related abuse, including revenge pornography, is on the Government's agenda and that following agreement by the Council of Australian Governments, a review of Commonwealth, State and Territory legislation is being undertaken 'to ensure it adequately criminalises the distribution of intimate material ... without the victim's consent'. See Jorge Branco, 'Revenge Porn Laws Needed "Sooner rather than Later", Sydney Morning Herald (online), 7 February 2016, <http://www.smh.com.au/queensland/revenge-porn-laws-neededsooner-rather-than-later-20160204-gmm432.html>. The Criminal Code Amendment (Private Sexual Material) Bill 2016 (Cth) was introduced on 17 October 2016.

30 Senate Committee, above n 1, 52 [5.19] Rec 3. 
possession, production or distribution of child exploitation material if the victim is under 17 years; ${ }^{31}$ blackmail; ${ }^{32}$ computer misuse offences; ${ }^{33}$ stalking; ${ }^{34}$ assault causing harm $;{ }^{35}$ intentionally or recklessly causing harm; ${ }^{36}$ criminal defamation ${ }^{37}$ and the intentional use of a listening device (other than in accordance with the Listening and Surveillance Devices Act 1972 (SA)) to overhear, record, monitor or listen to any private conversation, whether or not the person is a party to the conversation, without the consent, express or implied, of the parties to that conversation. ${ }^{38}$

The existing criminal offences of this type are, however, typically ill-suited to deal with revenge pornography scenarios. ${ }^{39}$ This prompted the introduction of the Summary Offences (Filming Offences) Act 2013 (SA) that introduced new specific offences to the Summary Offences Act 1953 (SA) to address revenge

31 Criminal Law Consolidation Act 1935 (SA) Part 3 Div 11A.

32 Ibid s 172

33 Ibid Part 4A.

34 Ibid s 19AA. See further Colette Langos, 'Regulating Cyberbullying: A South Australian Perspective' (2014) 16 (1) Flinders Law Journal 73-109.

35 Criminal Law Consolidation Act 1935 (SA) s 20(4). See further $R$ v Ireland [1997] 3 WLR 534.

36 Criminal Law Consolidation Act 1935 (SA) s 24. See further R v Ireland [1997] 3 WLR 534.

37 Criminal Law Consolidation Act 1935 (SA) s 257.

38 Listening and Surveillance Devices Act 1972 (SA) s 4. However, the principal offence in this Act does not apply to visual, data or tracking surveillance devices. See also the recently updated Surveillance Devices Act 2016 (SA) that will overcome this omission once it come into force.

39 NSW Standing Committee, above n 10, 36-7 [3.38]-[3.41], 39-40 [3.51]-[3.55]. The NSW DPP expressed a similar view. Existing laws do not 'encapsulate all types of harm' done by the dissemination and sharing of intimate and images and 'a specifically-targeted criminal offence would fill a gap within the existing law and go some way to addressing what is a growing — and highly damaging — concern within society.' See Belinda Merhab, 'NSW DPP Calls for Revenge Porn Laws', Courier Mail (online), 19 January 2016, <http://www.couriermail.com.au/news/breaking-news/nsw-dpp-call-for-revenge-pornlaws/news-story/fd9965e35da1fe65e8a5047ab806a54f>; Nicole Hasham, 'Woman whose Partner Coerced her into Sex with Prostitute Felt like "Performing Donkey", Inquiry Told', Sydney Morning Herald (online), 19 January 2016, <http://www.smh.com.au/federalpolitics/political-news/woman-whose-partner-coerced-her-into-sex-with-prostitute-felt-likeperforming-donkey-inquiry-told-20160119-gm8ubb.html>. 
pornography and cyber bullying ${ }^{40}$ (notably 'happy slappy' attacks). ${ }^{41}$ The Summary Offences (Filming and Sexting Offences) Amendment Act 2016 (SA) has now clarified and tightened these offences.

\section{The Present South Australian CRIMINAL LAW}

Section 26B of the Summary Offences Act 1953 (SA) addresses so called 'happy slappy' attacks. This provision makes it an offence to engage in humiliating or degrading filming or to take part in a humiliating or degrading act or to distribute a moving or still image obtained by humiliating or degrading filming knowing or having reason to believe that the victim does not consent to the distribution of the image. 'Humiliating or degrading act' means either an assault or other act of violence against the person or an act that reasonable adult members of the community would consider to be humiliating or degrading to such a person (but it does not include an act that reasonable adult members of the community would consider to cause only minor or moderate embarrassment). 'Humiliating or degrading filming' means filming images of another person while the other person is being subjected to, or compelled to engage in, a humiliating or degrading act. ${ }^{42}$

Section 26C covers the typical revenge pornography situation and provides that a person who distributes an 'invasive image' of another person, knowing or having reason to believe that the other person does not consent to the

40 South Australia, Parliamentary Debates, House of Assembly, 17 October 2012, 3250-3 (John Rau, Attorney-General). The 2013 Act 'addresses two concerns: the first one might call an invasion of dignity and the second an invasion of privacy': Ibid 3251. See further Langos, above $n 34$.

41 This disagreeable and inaptly named modern practice was described by the Attorney-General at the time of introducing the Summary Offences (Filming Offences) Act 2013 (SA) as follows: The internet, and the growth of social media on it, has brought a growing and unwelcome phenomenon. The central example of this particular evil is that there is some kind of fight or other criminal conduct involving a victim, provoked or not, unwitting or not, but the point is that the assault is filmed and then screened on the internet somewhere, presumably on YouTube, Facebook or a social media internet home page. A major result, usually intended, is the indiscriminate, pictorial humiliation of a victim. While there may be legal remedies against the assailants, it is unclear what can be done about those who further victimise the victim in this way...This Bill comes to terms with some of this anti-social behaviour.

South Australia, Parliamentary Debates, House of Assembly, 17 October 2012, 3250-1 (John Rau, Attorney-General). See also Victorian Law Reform Commission, Surveillance in Public Places (Final Report 18) (2010).

42 Summary Offences Act 1953 (SA) s 26A. 
distribution of the image is guilty of an offence. It is a defence to an offence under s 26B that the conduct in question was for a 'legitimate public purpose'. Conduct will be taken to be for a 'legitimate public purpose' only if the conduct was in the public interest having regard to: whether the conduct was for the purpose of educating or informing the public; whether the conduct was for a purpose connected to law enforcement or public safety; whether the conduct was for a medical, legal or scientific purpose and any other factor a court determining the charge considers relevant. ${ }^{43} \mathrm{~A}$ presumption arises that conduct engaged in, by or on behalf of a 'media organisation' was engaged in for a legitimate public purpose, unless the court, having regard to the matters set out above, finds that the conduct was in fact not for a legitimate public purpose. ${ }^{44}$

An image of a person is taken to be an 'invasive image' of a person if it depicts the person in a place other than a public place either engaged in a 'private act' or in a state of undress, such that in the case of a female the 'bare breasts' ${ }^{\text {} 45}$ are visible, or in any case, 'the bare genital or anal region is visible'. The section provides that an image of a person that 'falls within the standards of morality, decency and propriety generally accepted by reasonable adults in the community will not be taken to be an invasive image of the person' ${ }^{46}$ This test is a familiar concept and draws on comparable tests of reasonable community standards elsewhere in the criminal law. ${ }^{47}$ As an example, sending innocent images of a naked infant to family members would be likely to fall within the standards of morality, decency and propriety generally accepted by reasonable

43 Ibid s 26B(6).

44 Ibid s 26B(7). The Government explained it had strictly defined 'media organisation' for these purposes to limit the types of media organisations that receive the benefit of this provision to those licensed under the Broadcasting Services Act 1992 (Cth) and those that are members of the Australian Press Council or authorised under a law of the Commonwealth. It covered 'responsible' media outlets, and those organisations that are regulated, licensed or otherwise formally recognised as professional media organisations. The Opposition's amendment to the new Act to expand this definition was opposed by the Government as being too broad: South Australia, Parliamentary Debates, House of Assembly, 5 July 2016, 6224-5 (John Rau, Attorney-General).

45 The original Bill said 'breast' but the word 'bare' was added as a result of an Opposition amendment to bring greater clarity to the offence. See South Australia, Parliamentary Debates, Legislative Council, 23 June 2016, 4368-73. The Government ultimately accepted this amendment: see South Australia, Parliamentary Debates, House of Assembly, 5 July 2016, 6223 .

46 Summary Offences Act 1953 (SA) s 26A(3).

47 For example, for the offence of indecent assault, the word 'indecent' means contrary to the ordinary contemporary standards of respectable people in this community. See, eg, $R v$ Court [1989] AC 28; $R$ v Harkin (1989) 38 A Crim R 296. 
adults in the community and would be unlikely to be an offence under s $26 \mathrm{C} .{ }^{48}$ Section 26A of the Act defines a 'private act' as either 'a sexual act of a kind not ordinarily done in public', 'an act carried out in a sexual manner or context' or 'using a toilet'. The 'private region' of a person means the person's 'genital or anal region, or in the case of a female, the breast, when covered by underwear or bare'. ${ }^{49}$

Section 26D provides that it is an offence for a person to engage in indecent filming or to distribute a moving or still image obtained by indecent filming. It is a defence to a charge of an offence under s $26 \mathrm{D}$ that the party filmed consented to the distribution of the image or did not know, and could not reasonably be expected to have known, that the indecent filming was without the person's consent.

The previous offences under s 26C excluded the image of a child under 16 years from amounting to an invasive image. ${ }^{50}$ The new Act addresses this omission and an invasive image now include the images of children aged under 17 years. A person under 17 or with a 'cognitive impairment' is unable to provide consent to conduct within ss $26 \mathrm{~B}, 26 \mathrm{C}$ or $26 \mathrm{D} .{ }^{51}$

Section 26DA introduces new offences of threatening to distribute an invasive image or an image obtained from indecent filming and intending to arouse a fear that the threat will be, or is likely to be, carried out, or is recklessly indifferent as to whether such a fear is aroused. It is a defence to a charge of an offence under s 26DA if the person filmed consented to the distribution of the image that was the subject of the filming. The new offences under s 26DA apply to a threat directly or indirectly communicated by words (written or spoken) or by conduct, or partially by words and partially by conduct, and may be explicit or implicit.

48 South Australia, Parliamentary Debates, House of Assembly, 9 March 2016, 4602. See also South Australia, Parliamentary Debates, Legislative Council, 9 June 2016, 4248 (Hon A McLachlan).

49 Summary Offences Act 1953 (SA) s 26A.

50 The original s $26 \mathrm{C}$ did not include 'images of persons under 16 , because that is classified as child exploitation material, which of course is a completely separate kettle of fish': South Australia, Parliamentary Debates, House of Assembly, 17 June 2015, 1686 (John Rau, Attorney-General). See also: 'The rationale for this provision was so as not to intrude on the Criminal Law Consolidation Act child exploitation offences': South Australia, Parliamentary Debates, Legislative Council, 9 June 2016, 4248 (Hon A McLachlan).

51 Summary Offences Act 1953 (SA) s 26E. A 'cognitive impairment' is widely defined. 
The new offences in s 26DA have particular application to revenge pornography situations and overcome a significant omission in the previous law. Threats related to revenge pornography are a real problem. Submissions and witnesses to the recent Senate Committee 'argued that threats to disseminate intimate images - irrespective of whether or not those images exist - can have the same or similar impact as actual dissemination.' ${ }^{52}$ 'Sometimes, the threat is more potent than actually carrying out the conduct.' ${ }^{53}$

The new South Australian Act received all party support; although there was some debate about the extent of the media defence in s 26B (the Opposition sought to extend the definition of a 'media organisation') $)^{54}$ and concern was raised about offenders aged under 18 being charged with child exploitation

52 Senate Committee, above n 1, 18 [2.17]; see also 18-20 [2.18]-[2.22], 35-6 [3.39]-[3.41].

53 South Australia, Parliamentary Debates, House of Assembly, 17 May 2016, 5318 (Mr Tarzia).

54 South Australia, Parliamentary Debates, Legislative Council, 23 June 2016, 4373-8. The amendment sought to define a media organisation under s $26 \mathrm{~B}$ in similar expansive terms as in the Surveillance Devices Act 2016 (SA) as covering 'an organisation whose activities consist of or include the collection, preparation for dissemination or dissemination of the following material for the purpose of making it available to the public.' See South Australia, Parliamentary Debates, Legislative Council, 23 June 2016, 4373 (Hon A McLachlan). See also South Australia, Parliamentary Debates, Legislative Council, 20 September 2016, 47312. The Government opposed the amendment, arguing that it was too broad and would undermine the offence in s $26 \mathrm{~B}$ and allow irresponsible 'organisations' to masquerade as a 'media organisation'. See South Australia, Parliamentary Debates, House of Assembly, 5 July 2016, 6224-5 (John Rau, Attorney-General); South Australia, Parliamentary Debates, Legislative Council, 23 June 2016, 4374 (Hon P Malinauskas). The amendment was eventually defeated: see South Australia, Parliamentary Debates, Legislative Council, 20 September 2016, 4731-3. 
material offences and ending up on the Register for child sex offenders. ${ }^{55}$ Although this concern is not untenable, ${ }^{56}$ in South Australia it is misplaced. ${ }^{57}$

\section{THE CRIMINAL LAW IS Not ENOUGH}

The criminal law plays an important, though far from exclusive, role in addressing revenge pornography. The criminal law is not a silver bullet solution. Revenge pornography 'is a complex issue and ... criminalising it will not be sufficient in isolation. ${ }^{58}$ There are major issues in both enforcement ${ }^{59}$ (including police investigative priorities and technical and technological

55 A related Opposition amendment to the Statutes Amendment (Attorney-General's Portfolio) Bill 2016 (SA) was unsuccessfully moved in the Legislative Council. This amendment would have required the Attorney-General to consent to a person under 18 years of age being prosecuted for a child exploitation material offence. The rationale of this amendment was that there should be an extra protection to ensure that young people were not unnecessarily charged with serious child pornography offences for activities, notably consensual, non-exploitative sexting between young people, and to ensure such cases did not result in, a criminal record or being placed on the sex offenders register that can impact their life thereafter (especially by registration as a child sex offender) due to a moment of foolishness. See South Australia, Parliamentary Debates, House of Assembly, 23 March 2016, 4827 (Ms Chapman); South Australia, Parliamentary Debates, House of Assembly 17 May 2016, 5306-8, 5309 (Ms Chapman); South Australia, Parliamentary Debates, Legislative Council, 7 June 2016, 4145 6 (Hon A McLachlan); South Australia, Parliamentary Debates, Legislative Council, 9 June 2016, 4237 (Hon A McLachlan). The Government opposed this amendment as 'misconceived and both unnecessary and undesirable' and pointed out that it is not part of the AttorneyGeneral's role to be involved in the independent exercise of 'police and prosecutional direction' and there are individuals under the age of 18 whose offending is of such a serious nature that they should be properly charged with child exploitation material offences. South Australia, Parliamentary Debates, Legislative Council, 9 June 2016, 4237-8 (Hon P Malinauskas). See also South Australia, Parliamentary Debates, House of Assembly, 17 May 2016, 5308-9 (John Rau, Attorney-General). This amendment was eventually not passed.

56 See Crofts and Lee, above n 17; Salter, Croft and Lee, above n 17.

57 It is often overlooked that under the Child Sex Offenders Registration Act 2006 (SA), placing an offender in South Australia on the Register for child sex offences is purely discretionary for an offender aged under 18 years convicted of child sexual offences. No individual under 18 convicted of child exploitation material offences is presently on the Register; the one such offender who previously was on the Register had also been convicted of other serious sexual offences. See South Australia, Parliamentary Debates, House of Assembly, 17 May 2016, 5308 (John Rau, Attorney-General); South Australia, Parliamentary Debates, House of Assembly, 17 May 2016, 5307 (Ms Chapman).

58 Senate Committee, above n 1, 39 [4.1].

59 Ibid 22-4 [2.30]-[2.40]; NSW Standing Committee, above n 10, 22 [2.21], 37 [3.43], 40 [3.57]. 
challenges) ${ }^{60}$ and jurisdiction ${ }^{61}$ and Commonwealth and state legislation overlaps. ${ }^{62}$ The websites featuring revenge pornography 'usually span international borders and involve highly secretive website operators' ${ }^{63}$ The ease of instant transmission and distribution with technological advances is fundamental: '[O]nce an individual transmits an image via cell phone or over the Internet, it is virtually impossible to remove it. ${ }^{64}$ Even if the offender or original website can be persuaded to remove the image, there are 'dozens or even hundreds of other Web sites' which can redistribute these images. ${ }^{65}$

Given the limitations of the criminal law, it is important not to overlook civil remedies ${ }^{66}$ The various civil remedies such as the tort of negligence, nuisance,

60 NSW Standing Committee, above n 10, 22 [2.21]; Senate Committee, above n 1, $23-4$ [2.38][2.40]. The Australian Federal Police noted to the Senate Committee these offences are 'incredibly resource intensive' and while offering assurances that 'all crime is taken seriously', the AFP stated that 'all crime has to be prioritised. It is simply a resourcing issue ... With online crime, ultimately we will have to prioritise, and contact offences will always have a higher priority than non-contact offences, simply because of resources.' See $\mathrm{Mr}$ Connelly, AFP, Committee Hansard, 18 February 2016, 51, quoted by Senate Committee, above $\mathrm{n} 1,24$ [2.40].

61 Senate Committee, above n 1, 22-3 [2.30]-[2.34], 25 [2.46].

62 Ibid 23 [2.36], 37-9 [3.14]-[3.19].

63 Miles Godfrey, 'Revenge Porn Spreading like Wildfire', The Australian (online), 12 November 2013, <http://www.theaustralian.com.au/news/latest-news/revenge-pornspreading-like-wildfire/story-fn3dxiwe-1226766034486>. See also Senate Committee, above n 1, 22-3 [2.33]-[2.34]. As Fiona Neil notes:

Many websites are hosted in far-flung legal jurisdictions where new laws don't apply, or on the so-called 'dark net' - the Wild West of the internet, where everything is encrypted and users are anonymous. Without a coherent international reaction, many of the hackers and revenge-porn operators are likely to remain beyond the reach of the law. Nor will new laws address the main priority of victims, which is to get rid of the photos and videos as quickly as possible after they've been posted in an effort to prevent their spread. Even for celebrity clients, getting images removed from sites is a herculean task.

Fiona Neil, 'Revenge Porn: Emma Holten's radical way to hit back', The Australian (online), 2 May 2015, <http://www.theaustralian.com.au/life/weekend-australian-magazine/revengeporn-emma-holtens-radical-way-to-hit-back/newsstory/00b380ffb1981aa575f2a3ccd8097797>.

64 Elizabeth Ryan, 'Sexting: How the State Can Prevent a Moment of Indiscretion from Leading to a Lifetime of Unintended Consequences for Minors and Young Adults' (2010) 96 Iowa Law Review 357, 363.

65 Kitchen, above n 16, 251.

66 Though civil remedies have their own major issues, including delay and cost. See Kitchen, above n 16, 251-3; Senate Committee, above n 1, 42 [4.14], 53 [5.24]; Citron and Franks, above $\mathrm{n} 1,358$. 
the intentional infliction of nervous or emotional shock, ${ }^{67}$ copyright, defamation or trespass to land or goods typically do not apply to a revenge pornography situation. ${ }^{68}$ The equitable doctrine of breach of confidence ${ }^{69}$ may apply to revenge pornography ${ }^{70}$ but it is still seen to be a 'poor fit' to address revenge pornography 'due to it traditionally being applied to contractual or commercial relationships'. ${ }^{71}$ Courts have also generally proved reluctant to award equitable compensation for noneconomic loss and/or emotional distress not amounting to a recognised psychiatric illness resulting from a breach of confidence. $^{72}$

There are various other civil remedies that might arise such as a restraint order or injunction ${ }^{73}$ or recourse to the Office of the Children's eSafety Commissioner (whose powers include orders to take down offending material). ${ }^{74}$ However, as various law reform agencies have concluded, the civil legal picture, in the absence of an overarching tort or action to protect personal privacy, is one of incomplete and piecemeal remedies.

67 Wilkinson v Downton [1897] QB 57; Janvier v Sweeney [1919] 2 KB 316. Despite doubts in England (see Wainwright v Home Office [2004] 2 AC 406, 425), this tort seemingly remains part of Australian law. See, eg, Bunyan v Jordan (1937) 57 CLR 1; Nationwide News Pty Ltd v Naidu (2007) 71 NSWLR 471, [72].

68 South Australian Law Reform Institute, above n 10, 32-3 [5]-[11]. See also ALRC (2014), above n 10, 51-3 [3.50].

69 See generally NSW Standing Committee, above n 10, 42-6 [3.66]-[3.78].

70 See, eg, Giller v Procopets (2008) 24 VR 1; Wilson v Ferguson [2015] WASC 15.

71 NSW Standing Committee, above n 10, 47 [3.85]. See also NSW Standing Committee, above n 10, 46-7 [3.79]-[3.84]; South Australian Law Reform Institute, above n 1034 [17].

72 See ALRC (2014), above n 10, 26 [1.49], 267-70 [13.17]-[13.30]; South Australian Law Reform Institute, above n 10, 35 [18]. Cf Wilson v Ferguson [2015] WASC 15.

73 An injunction is a limited remedy. There will be many, if not most, cases, as in Wilson $v$ Ferguson [2015] WASC 15 [80], where there is no opportunity for any injunction to be sought or obtained between the time when a person forms the intention to distribute the victim's intimate images and the time when he or she achieves that purpose. An injunction may also prove an otiose remedy where "the distribution of the images has been so widespread that the grant of injunctive relief would serve no utility at this stage, or that the images have lost their confidential character by reason of the extent of their publication': Wilson v Ferguson [2015] WASC 15 [61] (Mitchell J).

74 This Office takes a civil rather than a criminal law response. See Senate Committee, above $\mathrm{n}$ 1, 39-40 [4.4]. 'The Office of the Children's eSafety Commissioner (OCeSC) is an independent statutory Commonwealth agency that operates under the Enhancing Online Safety for Children Act 2015(Cth) ... and has powers to take action on behalf of children who have been the victim of certain cybercrimes': Senate Committee, above n 1, 39 [4.2]. 
The Australian Law Reform Commission is clear that, in light of the major gaps in the present civil remedies to protect privacy, a general action for serious breach of privacy is both desirable and necessary. ${ }^{75}$ It noted that 'revenge pornography' might be 'an example of an outrageous invasion of privacy' that may justify the award of exemplary damages. ${ }^{76}$ The NSW Standing Committee on Law and Justice noted the 'particular concern' engendered by revenge pornography. ${ }^{77}$ The NSW Committee observed the understandable frustration expressed to it by interested parties at the lack of any civil law reform despite various 'eminent' law reform reports. ${ }^{78}$ The Committee noted that 'the vast majority' of interested parties had strongly argued before it for the introduction of a statutory cause of action 'on the basis that existing legal remedies were inadequate' to protect persons who suffered a serious invasion of privacy. ${ }^{79}$ The Committee was unimpressed with the existing civil remedies, noting:

[T] he bulk of evidence was that the available civil remedies, in particular the equitable action for breach of confidence, was inaccessible, offered a 'poor fit', and failed to offer [an] appropriate remedy to people who suffered a serious invasion of privacy. ${ }^{80}$

The NSW Standing Committee concluded that both civil and criminal ${ }^{81}$ law reforms were necessary to protect victims of revenge porn and others:

Privacy is an asset. Once it is lost, it cannot be recovered. The impacts of that loss can be devastating. The Committee agrees that there is a clear need to ensure better protection of privacy, and to provide adequate remedies to people who experience a serious invasion of privacy. ${ }^{82}$

The Committee recommended the introduction of a statutory civil cause of action for serious invasions of privacy. ${ }^{83}$

75 ALRC (2014), above n 10, 20 [1.17]. See also ALRC (2008), above n 10.

76 ALRC (2014), above n 10, 235 [12.84].

77 NSW Standing Committee, above n 10, 9.

78 Ibid.

79 Ibid 9; see also 57 [4.12].

80 Ibid 9; see also 45-6 [3.80]-[3.85].

81 Ibid 39-40 [3.55]-[3.51]: Although outside its terms of reference, the Committee recommended, in light of the limitations of the criminal law, that the NSW Government consider new criminal laws.

82 Ibid 9.

83 Ibid 57 Rec 3. See also Victorian Law Reform Commission (2009), above n 10. 
The South Australian Law Reform Institute, after examining the existing criminal and civil remedies in South Australia, reached a similar conclusion. ${ }^{84}$ 'The Institute has concluded that the protections presently available in South Australia for interferences with a person's privacy are inadequate.' 85 The Institute noted that a national tort or action for privacy is unlikely to emerge in the near future through either the courts ${ }^{86}$ or the Commonwealth Parliament (in light of the lack of support from the current Government). ${ }^{87}$ The Institute recommended that 'the South Australian Parliament should enact a limited cause of action for serious invasions of personal privacy.' 88

\section{CONClusion: THE NeEd FOR A COMPREHENSIVE SOLUTION}

The new South Australian Act, even in the absence of a comprehensive civil remedy, is still a welcome measure. As Mr Tarzia pointed out in the South Australian parliamentary debate:

technology has obviously changed and continues to change [and] with that change in technology, we as legislators always need to be on the front foot to ensure that we are able to set the necessary boundaries for our community, for the conduct of those in our area. ${ }^{89}$

However, revenge pornography is a complex contemporary issue. The new Act, as with any purely legislative approach, 'by itself will not necessarily solve this very difficult and complex issue'.$^{90}$ It is important, as concluded by both the NSW Standing Committee and the Senate Committee, to adopt a comprehensive solution. The Senate Committee believed that a range of measures should be implemented to combat the 'growing scourge' of revenge pornography; 'these measures should include criminal and civil law penalties,

84 South Australian Law Reform Institute, above n 10.

85 Ibid 15.

86 Ibid 31-2 [3]. See also ALRC (2014), above n 10, 53-5 [3.53]-[3.55].

87 South Australian Law Reform Institute, above n 10, 12-13. See also NSW Standing Committee, above n 10, 70 [4.79].

88 South Australian Law Reform Institute, above n 10, 26 Rec 1.

89 South Australia, Parliamentary Debates, House of Assembly, 17 May 2016, 5318 (Mr Tarzia).

$90 \quad$ Ibid 5319. 
public education and awareness campaigns, and professional training for police. ${ }^{91}$

These are all valid considerations. The need for enhanced police investigatory practices has been raised. ${ }^{92}$ There is also an obvious need for education and public awareness as part of any response to revenge pornography. ${ }^{93}$ Such education should extend to both potential victims (while avoiding 'victim blaming') $)^{94}$ and potential offenders to highlight, especially to minors, the perils of forwarding intimate images ${ }^{95}$ and to impress upon the community (including any potential offender) that revenge pornography is not a 'victimless' crime' and it is both unacceptable and unlawful to take or distribute intimate images of another without that person's explicit consent. ${ }^{96}$ As one party aptly commented to the Senate Committee:

The community must be educated that this is a crime. Such education is needed to combat the myths associated with revenge porn and other forms of violence, particularly against women. Revenge porn is to be taken seriously and community attitudes have a big part to play in challenging victim blaming attitudes. ${ }^{97}$

Any solution to the complex issue of revenge pornography 'is obviously not purely legislative ... However, the criminal law also has a vital role to play in declaring the boundaries of appropriate conduct. ${ }^{98}$ Though the criminal law is not, as this article has discussed, the exclusive means to address revenge

91 Senate Committee, above n 1, 49 [5.2].

92 NSW Standing Committee, above n 10, 22 [2.11], 37 [3.43], 40 Rec 1; Senate Committee, above n 1, 21-2 [2.28]-[2.29], 46-7 [4.33]-[4.37], 50 [5.10], 54-5 [5.37]-[5.41]; see also NSW Standing Committee, above n 10, 40 [3.57].

93 NSW Standing Committee, above n 10, Senate Committee, above n 1, 39 [4.1], 43-5 [4.18][4.27], 54 [5.32]-[5.36].

94 Senate Committee, above n 1, 43-4 [4.18]-[4.20]. See also South Australia, Parliamentary Debates, Legislative Council, 9 June 2016, 4250 (Hon K Vincent); South Australia, Parliamentary Debates, Legislative Council, 9 June 2016, 4251 (Hon T Franks).

95 See, eg, 'Educating Young People about the Risks of Sharing an Explicit Selfie is the First Step in Defusing the Problem': John Rau, Attorney-General, Revenge Porn: It's not OK, Press Release, $27 \quad$ October 2016, <http://www.agd.sa.gov.au/sites/agd.sa.gov.au/files/documents/Media\%20Releases/2016/O CT/20161028-MR-AG-RevengePorn.pdf>. See also above n 17.

96 Senate Committee, above n 1, 21-2 [2.29]-[2.30].

97 Ms Laughton, Victim Support Service, Committee Hansard, 18 February 2016, 2 quoted by Senate Committee, above n 1, 22 [2.29].

98 South Australia, Parliamentary Debates, House of Assembly, 9 March 2016, 4602 (John Rau, Attorney-General). 
pornography, it is still crucial in terms of both punishment and deterrence and in keeping up with technological advances and social practices and values and in setting the proper parameters of modern conduct. ${ }^{99}$ The new South Australian Act in this light is a timely legislative addition. As the AttorneyGeneral observed of the new Act:

Revenge porn has become a worrying issue in the community... the law has a crucial role in setting the boundaries of acceptable behaviour. These changes strengthen the criminal law — creating a major deterrent and strong penalties to curtail this phenomenon. ${ }^{100}$

99 Kitchen, above n 16, 261-3, 292-3. See also South Australia, Parliamentary Debates, House of Assembly, 17 May 2016, 5318-9 (Mr Tarzia).

100 Rau, above n 95. 